\title{
EVALUATION OF THE ANTIMICROBIAL ACTIVITY OF CRUDE EXTRACTS AND ISOLATED CONSTITUENTS FROM CHRESTA SCAPIGERA
}

\author{
Elisandra C. Schinor ${ }^{1,2 *}$; Marcos J. Salvador ${ }^{2,3}$, Izabel Y. Ito $^{4}$; Diones A. Dias ${ }^{1,2}$
}

\begin{abstract}
${ }^{1}$ Departamento de Química, Faculdade de Filosofia, Ciências e Letras de Ribeirão Preto, Universidade de São Paulo, Ribeirão Preto, SP, Brasil; ${ }^{2}$ Departamento de Física e Química, Faculdade de Ciências Farmacêuticas de Ribeirão Preto, Universidade de São Paulo, Ribeirão Preto, SP, Brasil; ${ }^{3}$ Instituto de Pesquisa e Desenvolvimento, Universidade do Vale do Paraíba, São José dos Campos, SP, Brasil; ${ }^{4}$ Departamento de Análises Clínicas, Toxicológicas e Bromatológicas, Faculdade de Ciências Farmacêuticas de Ribeirão Preto, Universidade de São Paulo, Ribeirão Preto, SP, Brasil
\end{abstract}

Submitted: January 14, 2005; Returned to authors for corrections: March 09, 2006; Approved: January 18, 2007

\begin{abstract}
Crude extracts and eight isolated compounds from Chresta scapigera were evaluated for antibacterial and antifungal activities by the agar-well diffusion method. Twenty strains, including Gram-positive and Gramnegative bacteria and yeasts were used in the bioassay. Hexane extracts presented the best results while ethanol extracts did not indicate inhibition of the microbial growth. Amongst the evaluated compounds $\beta$ amyrin acetate, tiliroside and luteolin showed the strongest antimicrobial effect.
\end{abstract}

Key words: Chresta scapigera, flavonoids, triterpenes, antimicrobial activity

\section{INTRODUCTION}

The emergence of human pathogenic microorganisms that are resistant to major classes of antibiotics has increased in recent years, due to the indiscriminate use of antimicrobial drugs (9). This has caused many clinical problems in the treatment of infectious diseases and the antibiotics commonly used are sometimes associated with adverse effects on the host, which include hypersensitivity, allergic reaction and immunosuppression (12). Therefore, research for development of new antimicrobial agents is an urgent need.

Plants are known to produce some chemicals, which are naturally toxic to bacteria and fungi (2). Traditionally, the dried herbs are used either as boiled in water to make a tea or as an infusion to treat systemic bacterial and fungal infections, as well applied directly on the skin or nails in a plaster form to treat local infections (20).

Some species of Asteraceae family present antimicrobial action, such as Arnica montana (8), Carthamus lanatus (17), Moquinia kingii (16). The genus Chresta, belonging to this family, comprises 12 endemic species of "Cerrado Brasileiro" (15) and there has been no reports about biological activities of plants belonging to this genus.

Thus, the aim of this investigation was to evaluate the in vitro antimicrobial activity of crude extracts (root, stem, leaves and inflorescence) and eight isolated compounds (kaempferol, apigenin, luteolin, tiliroside, crysoeriol, $\beta$-amyrin acetate, lupeol and $11 \alpha, 12 \alpha$-oxidetaraxeryl acetate) from Chresta scapigera against twenty strains of microorganisms, including Grampositive and Gram-negative bacteria and yeasts.

\section{MATERIALS AND METHODS}

\section{Plant material}

The plant material of Chresta scapigera was collected in Furnas (MG-Brazil) in July 1998, and identified by Dr. João Semir (Instituto de Biologia, Unicamp, Campinas, SP-Brasil). A voucher specimen is deposited in the Herbarium of Faculdade de Filosofia, Ciências e Letras de Ribeirão Preto/Universidade de São Paulo (register number SPFR 6874).

*Corresponding Author. Mailing address: Departamento de Física e Química, Fac. Ciências Farmacêuticas de Ribeirão Preto - USP - Av. do Café, s/n 14040-903 Ribeirão Preto, SP - Brasil. Tel.: (16) 633-2960. E-mail: ec.schinor@uol.com.br ou diones@ fcfrp.usp.br 


\section{Extraction and fractionation}

Roots $(188.0 \mathrm{~g})$, stem $(252.0 \mathrm{~g})$, leaves $(313.0 \mathrm{~g})$ and inflorescences $(99.0 \mathrm{~g})$ were separated, dried, powdered and stored in dark bags to protect them from humidity and light. The powdered material was extracted by maceration with $n$ hexane, dichloromethane and ethanol, respectively, at room temperature. The $n$-hexanic extract of roots $(9.521 \mathrm{~g})$ was chromatographed on a column of silica gel $60(0.063-0.200 \mathrm{~mm}$, Merck), eluted with hexane, ethyl acetate, methanol and mixtures of these solvents in increasing polarity. This extract furnished 18 fractions and the fractions 3 and 4 were purified by preparative thin layer chromatography (PTLC) yielding compounds (I) $(16 \mathrm{mg})$ and (II) $(10 \mathrm{mg})$. The $n$-hexanic extract of inflorescences (2.594 g) was chromatographed using the same conditions and furnished 14 fractions. Preparative TLC was used to purify the fraction 4 , which yielded compound (III) (30 $\mathrm{mg})$. The ethanolic crude inflorescence extract $(2.6 \mathrm{~g})$ was partitioned between dichloromethane and methanol. The hidroalcoholic phase $(1.3 \mathrm{~g})$ was submitted to filtration on sephadex LH-20 and the fractions 6 and 7 were purified by preparative high performance liquid chromatography (HPLC) in reverse phase (column ODS Shimadzu $5 \mu \mathrm{m}, 20$ x $250 \mathrm{~mm}$, eluent: methanol:water in gradient, flow $9 \mathrm{~mL} / \mathrm{min}, \mathrm{UV}$ detection: $280 \mathrm{~nm}$ ) resulting in compounds (IV) $(22 \mathrm{mg}),(\mathbf{V})(12 \mathrm{mg})$ and (VI) $(10 \mathrm{mg})$. While the dichloromethanic phase (391 mg) was chormatographed on a silica gel column and was eluted with hexane, ethyl acetate, methanol and mixtures of these solvents in increasing polarity. The fraction 3 was purified by preparative TLC resulting in compound (VII) $(3 \mathrm{mg}$ ). The ethanolic crude extract of stem was chromatographed on polyvinylpyrrolidone by vacuum liquid chromatography eluted with $\mathrm{CHCl}_{3}$, methanol and mixtures of these solvents in increasing polarity. Filtration on sephadex LH-20 was used to purify the fraction 1, which yielded compounds (V) (2 mg), (VII) (3 mg) and (VIII) (3 mg).

The structures of all compounds were determined by ${ }^{1} \mathrm{H}-$ $\mathrm{NMR}$ and ${ }^{13} \mathrm{C}$-NMR spectra, which were measured in $\mathrm{CDCl}_{3}$ (for triterpenes) and DMSO- $\mathrm{d}_{6}$ (for flavonoids) using tetramethylsilane as the internal standard by a BRUCKER DRX instrument (400MHz for ${ }^{1} \mathrm{H}$ and $100 \mathrm{MHz}$ for ${ }^{13} \mathrm{C}$ ).

\section{Antimicrobial activity}

Crude extracts and isolated compounds were tested for antimicrobial activity against twenty strains of microorganisms including Gram-positive and Gram-negative bacteria and yeasts. The following microorganisms were used: Escherichia coli ATCC 10538; Pseudomonas aeruginosa - ATCC 27853; P. aeruginosa - 290 D (field strain); Kocuria rhizophila - ATCC 9341; Staphylococcus aureus - ATCC 25923 and 6538; S. aureus 7+ penicilinase producer; S. aureus 8- penicilinase nonproducer; Staphylococcus epidermidis 6ep and epiC (field strain); Candida albicans - ATCC 1023; C. albicans cas and Candida tropicalis ct (field strains), cultivated for 24 hours at $37^{\circ} \mathrm{C}$ in Mueller Hinton broth (Difco) - MHb; Enterococcus faecalis - ATCC 10541; Streptococcus mutans - ATCC 25175; S. mutans (strains 11.1; 9.1; fab3; 11.2) and Streptococcus sobrinus 180.3 (field strains), incubated for 24 hours at $37^{\circ} \mathrm{C}$ in Brain Heart Infusion (Difco) - BHI. The standard and field strains (oral cavity) were provided by Departamento de Análises Clínicas, Toxicológicas e Bromatológicas, Faculdade de Ciências Farmacêuticas de Ribeirão Preto, Universidade de São Paulo, Ribeirão Preto - SP, Brasil.

Sensitivity tests were performed by a modified agar-well diffusion method (well technique in double layer) according to Okeke et al. (14), Cole (3), Grove and Randall, (7). The Mueller Hinton Medium (Difco) - MH agar plates, containing an inoculum size of $10^{6} \mathrm{cfu} / \mathrm{mL}$ of Escherichia, Pseudomonas, Kocuria, Staphylococcus and Candida strains or $10^{6} \mathrm{cfu} / \mathrm{ml}$ of Enterococcus and Streptococcus strains on Brain Heart Infusion Agar (Difco) - BHIa plates, were used. The inoculum size of each tested strain was standardized according to Clinical and Laboratory Standard Institute (13). Subsequently, aliquots of $20 \mu \mathrm{l}$ of each test-sample solution were applied into $5.0 \mu \mathrm{m}$ diameter wells. Solutions were prepared in propyleneglycol/ sterile water (5:95) at $5000 \mathrm{mg} / \mathrm{ml}$ for the crude extracts and 2500 $\mathrm{mg} / \mathrm{ml}$ for pure compounds in the screening. After incubation at $37^{\circ} \mathrm{C}$ for 24 hours, the inhibition zone corresponding to the halo (h) formed from well edge to the beginning of the region of microbial growth was measured in millimeters $(\mathrm{mm})$. In the tests, bacitracine $(0.2 \mathrm{UI} / \mathrm{ml})$ and ketoconazole $(100 \mu \mathrm{g} / \mathrm{ml})$ were used as positive experimental controls for bacteria and fungi strains, respectively, and propyleneglycol/sterile water (5:95) as negative experimental control.

The minimal inhibitory concentration (MIC) was determined for each isolated compound using the agar diffusion method to give a concentration between 25 and $2500 \mathrm{mg} / \mathrm{ml}(5,6,14,18)$. In MIC determination, media containing sterile water and propyleneglycol (5:95) was used as negative control in which any inhibitory effect could be observed.

The tests were performed in duplicates for each microorganism evaluated and the final results were presented as the arithmetic average.

\section{RESULTS}

The chemical structures of all isolated compounds were determined by ${ }^{1} \mathrm{H}$-NMR and ${ }^{13} \mathrm{C}$-NMR spectra and $\beta$-amyrin acetate (I), 11a,12 $\alpha$-oxidetaraxeryl acetate (II), lupeol (III), tiliroside (IV), apigenin (V), kaempferol (VI), crysoeriol (VII), luteolin (VIII) were identified by a comparison with the literature values $(10,19)$.

The data for antibacterial and antifungal activities for the crude extracts and the isolated compounds of $C$. scapigera are show in Table 1 and Table 2, respectively. The antimicrobial activity assay was performed for crude extracts and isolated 
Table 1. Antimicrobial activity of the crude extracts from Chresta scapigera using diffusion method.

\begin{tabular}{|c|c|c|c|c|c|c|c|c|c|c|}
\hline \multirow[t]{2}{*}{ Microorganisms } & A & $\mathrm{B}$ & $\mathrm{C}$ & $\mathrm{D}$ & $\mathrm{E}$ & $\mathrm{F}$ & G & $\mathrm{H}$ & $\begin{array}{l}\text { Bacitracine } \\
(0.2 \mathrm{UI} / \mathrm{ml})^{\mathrm{a}}\end{array}$ & $\begin{array}{l}\text { Ketoconazole } \\
(100 \mathrm{mg} / \mathrm{ml})^{\mathrm{a}}\end{array}$ \\
\hline & $\mathrm{h}$ & $\mathrm{h}$ & $\mathrm{h}$ & $\mathrm{h}$ & $\mathrm{H}$ & $\mathrm{h}$ & $\mathrm{h}$ & $\mathrm{h}$ & $\mathrm{h}$ & $\mathrm{H}$ \\
\hline Staphylococcus aureus (ATCC 6538$)^{\mathrm{b}}$ & 8 & 12 & 8 & 8 & - & - & - & - & 23 & - \\
\hline S. aureus penicilinase $+(7+)^{\mathrm{c}}$ & 12 & 14 & 5 & 3 & - & - & - & - & 25 & - \\
\hline S. aureus penicilinase $-(8-)^{c}$ & - & 10 & - & 7 & - & - & - & - & 25 & - \\
\hline Staphylococcus epidermidis $(6 \mathrm{ep})^{\mathrm{c}}$ & - & - & - & - & - & - & - & - & 31 & - \\
\hline S. epidermidis (epiC) ${ }^{c}$ & - & - & - & - & - & - & - & - & 31 & - \\
\hline Kocuria rhizophila (ATCC 9341) & - & 10 & - & 12 & - & - & - & - & 25 & - \\
\hline Enterococcus faecalis (ATCC 10541) & - & - & - & - & - & - & - & - & 28 & - \\
\hline Streptococcus mutans (ATCC 25175) & 9 & - & 8 & - & - & - & 8 & - & 24 & - \\
\hline S. mutans (fab3) ${ }^{\mathrm{c}}$ & - & - & - & - & - & - & - & - & 22 & - \\
\hline S. mutans $(9.1)^{\mathrm{c}}$ & 9 & - & 8 & - & 9 & 10 & 10 & 10 & 22 & - \\
\hline S. mutans $(11.1)^{\mathrm{c}}$ & 10 & 11 & 9 & 10 & - & - & 7 & - & 22 & - \\
\hline S. mutans $(11.2)^{\mathrm{c}}$ & - & 12 & - & 8 & - & - & - & - & 22 & - \\
\hline Streptococcus sobrinus $(180,3)^{\mathrm{c}}$ & - & - & - & - & - & - & - & - & 23 & - \\
\hline Escherichia coli (ATCC 10538) & 7 & 11 & 8 & 10 & - & - & - & - & 32 & - \\
\hline Pseudomonas aeruginosa (ATCC 27853) & 11 & 15 & 9 & 15 & - & - & - & - & 22 & - \\
\hline P. aeruginosa $(290 \mathrm{D})^{\mathrm{c}}$ & - & - & - & - & - & - & - & - & 22 & - \\
\hline Candida albicans $(\mathrm{cas})^{\mathrm{c}}$ & - & - & - & - & - & - & - & - & - & 30 \\
\hline C. albicans (ATCC 1023) ${ }^{\mathrm{b}}$ & - & - & - & - & - & - & - & - & - & 30 \\
\hline Candida tropicalis $(\mathrm{ct})^{\mathrm{c}}$ & - & - & - & - & - & - & - & - & - & 15 \\
\hline
\end{tabular}

$\mathrm{h}$ : halo of inhibition in $\mathrm{mm} ;$ - : not active at $5000 \mu \mathrm{g} / \mathrm{ml}$; A: hexane extract of inflorescence; B: hexane extract of stem; C: hexane extract of leaves; D: hexane extract of root; E: dichloromethane extract of inflorescence; F: dichloromethane extract of stem; G: dichloromethane extract of leaves; $\mathrm{H}$ : dichloromethane extract of root; a: positive control; b: standard strain, c: field strain (oral cavity).

compounds against 14 strains of Gram-positive bacteria, 3 strains of Gram-negative bacteria and 3 strains of yeast. Among the crude extracts evaluated, the hexanic extracts were active and inhibited the growth of S. aureus, K. rhizophila, S. mutans, E. coli and P. aeruginosa. As indicated in Table 2, the bioactive compounds were mainly flavonoids and triterpenoids.

The bacitracine $(0.2 \mathrm{UI} / \mathrm{mL})$ here used as a positive experimental control against all bacteria strains assayed, produced halo of inhibition $(\mathrm{H})$ of $22-32 \mathrm{~mm}$, while ketoconazole $(100 \mu \mathrm{g} / \mathrm{mL})$ served as the positive experimental control for all fungi strains assayed with halo of inhibition of $15-30 \mathrm{~mm}$ (Table 1). The media containing propyleneglycol/RPMI-1640 (5:95) was used as negative control for which no inhibitory effect could be observed.

\section{DISCUSSION}

As shown in Table 1, all the hexanic extracts obtained from C. scapigera inhibited the growth of the bacterial strains and yeast, including P. aeruginosa (ATCC 27853) and E. coli (ATCC 10538), while the ethanolic extracts did not interfere in the microbial growth at $5000 \mu \mathrm{g} / \mathrm{ml}$. The dichloromethanic extracts were weakly active against $S$. mutans (strain 9.1). The screening conducted with compounds isolated from $C$. scapigera revealed that the antimicrobial activity was associated mainly with Gram-positive bacteria and yeasts (Table 2). Among the evaluated flavonoids, luteolin, which has a hydroxyl group at the 3' position, showed antimicrobial activity on S. mutans, S. aureus and C. tropicalis strains, whereas apigenin had very little effect. Crysoeriol, a 3'methoxy-flavone, did not affect the growth of the evaluated microorganisms. Thus, a hydroxyl group at the 3' position can be responsible for the antimicrobial activity. This is in agreement with results presented by Yamamoto and Ogawa (19). Among flavonoids evaluated kaempferol was the most active, being active against great number of microorganisms at $500 \mu \mathrm{g} / \mathrm{ml}$, while tiliroside, an kaempferol derivative with a acil-glicoside portion, presented activity mainly at $2500 \mu \mathrm{g} / \mathrm{ml}$ (Table 2).

Flavonoids are known to be synthesized by plants in response to microbial infection. Hence, it should not be surprising that they have been found to be effective antimicrobial substances against a wide array of microorganisms, when tested in vitro. Their activity is probably due to their ability to react with extracellular and soluble proteins and to complex with bacterial cell walls (4). 
Table 2. Antimicrobial minimum inhibitory concentration activity of the isolated compounds from Chresta scapigera.

\begin{tabular}{|c|c|c|c|c|c|c|c|c|}
\hline \multirow{2}{*}{ Microorganisms } & \multicolumn{8}{|c|}{$\mathrm{MIC}(\mu \mathrm{g} / \mathrm{ml})$} \\
\hline & I & II & IIII & IV & $\mathrm{V}$ & VI & VII & VIII \\
\hline Staphylococcus aureus (ATCC 6538) & 500 & 500 & 500 & 2500 & 100 & 2500 & 500 & - \\
\hline S. aureus (ATCC 25923) ${ }^{\mathrm{a}}$ & 500 & 500 & 500 & 500 & 100 & - & 100 & - \\
\hline S. aureus penicilinase $+(7+)^{\mathrm{b}}$ & 500 & - & - & 2500 & 500 & - & 500 & - \\
\hline S. aureus penicilinase $-(8-)^{\mathrm{b}}$ & 2500 & - & - & 2500 & - & - & - & - \\
\hline Staphylococcus epidermidis $(6 \mathrm{ep})^{\mathrm{b}}$ & 500 & - & - & 500 & 500 & - & - & - \\
\hline S. epidermidis (epiC) ${ }^{\mathrm{b}}$ & 500 & - & - & 2500 & 500 & - & - & - \\
\hline Kocuria rhizophila (ATCC 9341) & - & - & - & - & - & - & - & - \\
\hline Enterococcus faecalis (ATCC 10541) & 2500 & - & - & - & 500 & - & - & - \\
\hline Streptococcus mutans (ATCC 25175) & 2500 & - & - & 2500 & - & - & 500 & - \\
\hline S. mutans $(\mathrm{fab} 3)^{\mathrm{b}}$ & - & - & - & - & - & - & - & - \\
\hline S. mutans $(9.1)^{\mathrm{b}}$ & 2500 & - & - & 2500 & 500 & - & - & - \\
\hline S. mutans $(11.1)^{\mathrm{b}}$ & 2500 & - & - & 2500 & 500 & - & - & - \\
\hline S. mutans $(11.2)^{\mathrm{b}}$ & 2500 & - & - & 2500 & 500 & - & - & - \\
\hline Streptococcus sobrinus $(180,3)^{\mathrm{b}}$ & 2500 & - & - & 2500 & 500 & - & 500 & - \\
\hline Escherichia coli (ATCC 10538) ${ }^{\mathrm{a}}$ & - & - & - & - & 2500 & - & 2500 & - \\
\hline Pseudomonas aeruginosa (ATCC 27853) & - & - & - & - & - & - & - & - \\
\hline P. aeruginosa $(290 \mathrm{D})^{\mathrm{b}}$ & - & - & - & - & - & - & - & - \\
\hline Candida albicans $(\mathrm{cas})^{\mathrm{b}}$ & 2500 & - & - & 2500 & - & - & - & - \\
\hline C. albicans (ATCC 1023) ${ }^{\mathrm{a}}$ & 2500 & - & - & 2500 & - & 2500 & - & - \\
\hline Candida tropicalis $(\mathrm{ct})^{\mathrm{b}}$ & 2500 & 2500 & 2500 & 2500 & - & 2500 & - & - \\
\hline
\end{tabular}

MIC: Minimum Inhibitory Concentration in $\mu \mathrm{g} / \mathrm{ml}$; —: without inhibitory activity; ${ }^{a}$ : standard strain; ${ }^{\mathrm{b}}$ : field strain (oral cavity).

There are some reports showing that polar extracts inhibited the growth of both Gram-positive and Gram-negative bacteria $(9,11)$. However in the present work, the ethanolic extracts of $C$. scapigera were inactive at $5000 \mu \mathrm{g} / \mathrm{ml}$ against all tested microorganisms. This can be explained by the chemical composition of the evaluated extracts, since a variation in concentrations of the active compounds present in these extracts can occur as well as antagonism effects. Despite this, the compounds (IV), (V), (VI) and (VII) were isolated of ethanolic extracts and were active against some of the tested microorganisms.

The obtained results for the hexanic extracts indicate the presence of antimicrobial constituents in these extracts. Bioactive compounds, such as (I), (II) and (III), were isolated from hexanic extract. Among the triterpenes, compound (I) was the most active on Gram-positive bacteria and yeast strains at concentrations ( 2500 and $500 \mathrm{mg} / \mathrm{ml}$ ).

Our data showed that the response in terms of susceptibility to tested drugs varied among the strains. The differences in susceptibility may be explained by differences in cell wall composition and/or genetic content of plasmids that can be easily transferred among bacterial strains (9).

In conclusion, our results demonstrated that hexanic and dichloromethanic crude extracts and flavonoids and triterpenoids isolated from C. scapigera present antimicrobial activity. However, further studies about the safety and toxicity of the extracts and isolated compounds are needed, in order to evaluate possible clinical application in therapy of infectious diseases.

\section{ACKNOWLEDGEMENTS}

We wish to thank FAPESP and CNPq by financial support and to Prof. Dr. Walter Vichnewski for collecting the plant material.

\section{RESUMO}

\section{Avaliação da atividade antimicrobiana dos extratos brutos e dos constituintes de Chresta scapigera}

Os extratos brutos e oito constituintes isolados de Chresta scapigera foram avaliados para as atividades antibacteriana e antifúngica, utilizando o método de difusão em ágar. Vinte cepas indicadoras, incluindo bactérias (Gram-positivas e Gramnegativas) e leveduras, foram utilizadas no bioensaio. Os melhores resultados foram obtidos para os extratos hexânicos, 
enquanto os extratos etanólicos não inibiram o crescimento microbiano. Acetato de $\beta$-amirina, tilirosídeo e luteolina foram os mais eficazes dentre os constituintes avaliados.

Palavras-chave: Chresta scapigera, flavonóides, triterpenos, atividade antimicrobiana

\section{REFERENCES}

1. Atta-ur-Rahman, V.U.A. (1994). Handbook of natural products data, v.2.

2. Basile, A.; Giordano, S.; López-Sáez, J.A.; Cobianchi, R.C. (1999). Antibacterial activity of pure flavonoids isolated from mosses. Phytochemistry, 52: 1479-1482.

3. Cole, M.D. (1994). Key antifungal, antibacterial and anti-insect assays - a critical review. Biochem. Syst. Ecol., 22: 837-856.

4. Cowan, M.M. (2002). Plant products as antimicrobial agents. Clin Microbiol. Rev., 12: 564-582.

5. Giesbrecht, A.M.; Barbosa, R.C.C.; Paula, C.R. (1987). In vitro study of the antibiotic activity of diterpenes. Braz. J. Med. Biol. Res., 20: 807-810.

6. Giesbrecht, A.M.; Davino, S.C.; Nassis, C.Z.; Young, M.C.; Lopes, J.L.C.; Rodrigues, D.C.; Vichnewski, W.; Nasi, A.M.T.T.; Dias, D.A Lopes, J.N.C. (1990). Antimicrobial activity of sesquiterpene lactones. Quím. Nova, 13: 312-314.

7. Grove, D.C.; Randall, W.A. (1955). Assay methods of antibiotics: a laboratory manual (Antibiotics monographs, 02), Medical Encyclopedia Inc, New York.

8. Iauk, L.; Lo Bue, A.M.; Milazzo, I.; Rapisarda, A.; Blandino, G. (2003). Antibacterial activity of medicinal plant extracts against periodontopathic bacteria. Phytother. Res., 17: 599-604.

9. Karaman, I.; Sahin, F.; Güllüce, M.; Ögütçü, H.; Sngül, M.; Adigüzel, A. (2003). Antimicrobial activity of aqueous and methanol extracts of Juniperus oxycedrus L. J. Ethnopharmacol., 85: 231-235.
10. Mabry, T.J.; Markhan, K.R.; Thomaz, M.B. (1970). The systematic identification of flavonoids, (Ed.: Spring-Verlog), Berlin.

11. Masika, P.J.; Afolayan, A.J. (2002). Antimicrobial activity of some plants used for the treatment of livestock diseases in Eastern Cape, South Afr. J. Ethnopharmacol., 83: 129-134.

12. Mukherjee, P.K.; Saritha, G.S.; Suresh, B. (2002). Antimicrobial potential of two different Hypericum species available in India Phytother. Res., 16: 692-695.

13. National Commitee for Clinical Laboratory Standards. (2003). Methods for Dilution Antimicrobial Susceptibility Tests for Bacteria that Grow Aerobically; Approved Standard - Sixth Edition - NCCLS document M7-A6 [ISBN 1-56238-486-4]. National Commitee for Clinical Laboratory Standards, 940 west Valley Road, Suite 1400, Wayne, Pennsylvania 19087-1898 USA.

14. Okeke, M.I.; Iroegbu, C.V.; Eze, E.N.; Okoli, A.S.; Esimone, C.O. (2001). Evaluation of extracts of the roots of Landolphia oweeunce for antibacterial activity. J. Ethnopharmacol., 78: 119-127.

15. Robinson, H. (1999). In: Generic and subtribal classidication of American Vernonieae, (Ed.: Smithsonian Institution Press), Smithsonian Contributions to Botany, Washington, DC, p.9-12.

16. Schinor, E.C.; Salvador, M.J.; Ito, I.Y.; Albuquerque, S.; Dias, D.A. (2004). Trypanocidal and antimicrobial activities of Moquinia kingii. Phytomedicine, 11: 224-229.

17. Taskova, R.; Mitova, M.; Najdenski, H.; Tzvetkova, I.; Duddeck, H. (2002). Antimicrobial activity and cytotoxicity of Carthamus lanatus. Fitoterapia, 73: 540-543.

18. Tereschuk, M.L.; Quarenghi de Riera, M.; Castro, G.R.; Abdala, L.R. (1997). Antimicrobial activity of flavonoids from leaves of Tagetes minuta. J. Ethnopharmacol., 56: 227-232.

19. Yamamoto, H.; Ogawa, T. (2002). Antimicrobial activity of perilla seed polyphenols against oral pathogenic bacteria. Biosci. Biotechnol. Biochem., 66: 921-924.

20. Yang, X.; Summerhurst, D.K.; Koval, S.F.; Ficker, C.; Smith, M.I.; Bernards, M.A. (2001). Isolation of an antimicrobial compound from Impatiens balsamina L. using bioassay-guided fractionation. Phytother. Res., 15: 676-680. 